\title{
A Cross-Cultural Study of Some Selected Arabic Proverbs and Their English Translation Equivalents: A Contrastive Approach
}

\author{
Marwa Essam Eldin Fahmi \\ English Department, College of Foreign Languages \& Translation, MISR University for Science \& Technology, Egypt
}

Received: 25-02-2016

Accepted: 27-03-2016

Published: 01-04-2016

doi:10.7575/aiac.ijclts.v.4n.2p.51

URL: http://dx.doi.org/10.7575/aiac.ijclts.v.4n.2p.51

\begin{abstract}
The main aim of this study is to examine some common proverbs in Arabic and their English counterparts to shed light on significant socio-cultural differences. The choice of sample proverbs is based upon thematic classification. Proverbs are words combined together to form larger semantic units which are encoded by the speaker and decoded by the hearer by means of their underlined knowledge of the language itself. Proverbs, as metaphoric expressions or as cultural discourse, are codified on semantic structures. Thereby, Proverbs are figural and signifying acts of meaning that mediate interpretation and negotiate pragmatic signification at linguistic, philosophical and cultural levels. While proverbs make up and reflect the cultural identity of a specific society, and despite the uniqueness of languages and the profound differences between cultures, there are proverbs that shed light on universal truths of human life, common traditions and beliefs. Such proverbs have bridged linguistic and cultural barriers throughout human history.
\end{abstract}

Keywords: Equivalence - English/Arabic Proverbs-Intercultural competence - Phraseology -Socio-semiotics

\section{Introduction}

\subsection{Aim and Scope}

The main aim of this study is to examine some common proverbs in Arabic and their English counterparts to shed light on significant socio-cultural differences. A contrastive approach is adopted to identify the dissimilarities between these equivalent proverbs in the two languages and the cultural differences reflected by them. The choice of sample proverbs is based upon thematic classification. The thematic approach involves the contrast of authentic as well as representative reactions of members of two cultural communities, Arabic and English, to particular similar situations, in their attempt to reinforce their points of view through the use of proverbial expressions.

\subsection{Research Questions}

Exposure to proverbs in both the Arabic and the English languages can transform one's perceptions and values regarding cultural diversity and can also facilitate new understanding and insights into the foreign cultural concepts enhancing intercultural competence. Two questions, thus, are explored:

1. To what extent the use of proverbs in the Arabic language can shed light on cultural aspects?

2. To what extent the use of proverbs in the Arabic language can promote a new understanding of the Arabic culture among native speakers of Arabic Language and make them discover and reassess their own values and preferences?

Language and culture are entwined: Language is used to express one's ideas thus expressing the worldview of that culture. The difference in language has made different people to have different worldviews though they share the same culture. Proverbs are synthesis of observations of social life, natural phenomena and the code determining people's relationships, testament of ancestors that is necessary for education of generations. Proverbs, as a result of their metaphorical essence, become a very significant aspect of the use of language. According to Hofstede's conception, culture is always a collective phenomenon because it is at least partly shared with people who live within the same social environment, which is where it was learned. Culture is learned, not inherited. It derives from one's social environment, not from one's genes. Culture should be distinguished from human nature on one side, and from an individual's personality on the other (Hofstede, 1991, p. 4).In the same line of thought, Suasn Bassnett illustrates that " no language can exist unless it is steeped in the context of culture, and no culture can exist which does not have at its center, the structure of natural language" (Bassnett, 2002, p. 22). It echoes Plato's analogy of the body and spirit in which culture is the spirit within the body of language, and it is their union that makes the "continuation of life energy" (Bassnett, 2202, p. 22).

\subsection{Definitions and Perspectives}

The English lexical item proverb goes back to the Middle Ages. It originated from the Latin proverbium, meaning "a short sentence that people often quote which gives advice or tells you something about life" (www.collinsdictionary.com). The Arabic for proverb is the lexical item مثنل (مفرد) - أمثال (جمع) which basically means (الحجة و الحديث" (الفيروز أبادى، The Arabic-speaking peoples have a tremendous store of proverbs; what is 
more, they are extremely fond of them, and proverbs have a definite place in their daily life. They often have poetic or other literary value, or they may sum up the wisdom and philosophy of the people.

The Arabic cultural background is quite different from the English one. The former is based on Islamic religion and Arab desert "Bedouin" environment, whereas the latter is based on Greek and Roman heritage, Christianity and its cold weather. These cultural differences between the two languages resulted in major differences between expressions like idioms and proverbs in both languages (Nadjib, 2001).For instance, في أحضان الصحر اء means literally in the bosom of desert, whereas English might say in the heart of desert. This Arabic collocation embodies a sense of embrace and welcome within the desert rather than the sense of hostility and hardship often associated with desert by those unfamiliar with such region.

Regarding culture-bound expressions, the following example might be helpful to foreground the socio-cultural differences between the two languages in question: $D$ D Five for the Arabs represents the five fingers of the hand; each finger symbolizes one of the verses "ayat" of "Surat Al Falak" (from the Holy Koran), combining a manual rite which is deemed to keep evil and envy away, whereas the English use the expression to touch the wood to avoid bad luck and keep the envy away. Such expressions and others associated with culture-bound terms are generally left out in translation because of their alien nature or replaced by other items that have approximately the same significance in the target culture if available. Thus, the cultural aspects of language play a significant role in translating idioms and proverbs and the "attempts of mere rendering or mere linguistic meaning transference of idiomatic and proverbial expressions from one language to another are deemed to result a bad product" (Dagust, 1976, p. 28).

Language can lack the concept itself. In every language, there are culture-bound terms and expressions which represent specific not general features peculiar to the culture of this language. The Arabs do not understand what baby/bridal shower, garage sale, Amish country, harvest festival or thanksgiving meaning because they lack the concepts in their environmental experience. On the other hand, العدة، التبرج، السحور، الخلوة، العقيقة are incomprehensible concepts for the English because they do not exist in their own culture and are considered totally strange.

Much is known about proverbs, their function, what they sound like, their age, and what the story is behind them, but there is still much debate as to what, exactly, constitutes a proverb (Mieder, 1993) and "little is known about the cognitive foundations of proverb production, pragmatics, expertise, emotion, or about the micro cognitive aspects of proverb comprehension" (Honeck, 1997, p. 276). There are different definitions of a proverb, such as -a short saying in general use, held to embody a general truth as defined by the Concise Oxford English Dictionary (2011), or - a condensed but memorable saying embodying "a truth which relates to everyday experience"(Seidle \& McMordi, 1978, p. 241) or - a complex, intriguing, and important verbal entity (Honeck, 1997, vii). These definitions and others indicate that proverbs are a society's way to guide its members on how to act in a difficult given situation and to provide advice for problem solving. The three main pillars on which proverbs are set up are truth, advice and wisdom, these are usually presented in "expressive and picturesque language" (Coles, 1979).

\section{Proverbs: Signifiers of Metaphor}

The term 'metaphor' was originally coined by the great Greek philosopher Aristotle who saw the power of metaphor in allowing people to produce knowledge. It is traditionally defined as "the use of a word or phrase denoting one kind of idea or object in place of another word or phrase for the purpose of suggesting a likeness between the two" (Danesi \& Perron, 1999, p. 162). This tradition analysis of metaphor has assumed that metaphor involves a deviation from ordinary and straight-forward usage of language in order to cause a change in meaning based upon similarities between two things. Later on, the concept of metaphor developed, in which it was no longer viewed as a verbal ornamentation or a stylistic device; rather, it has become realized as an effective device in communication. George Lakoff \& Mark Johnson (1980), forerunners in proving the presence of metaphors in everyday thought and discourse, rightly propose that metaphor is a verbal representation of abstract thinking in everyday life. In their insightful research, they argue

Metaphor is for most people a device of the poetic imagination and the rhetorical flourish - a matter of extraordinary rather than ordinary language. Moreover, metaphor is typically viewed as characteristic of language alone, a matter of words rather than thought and action ... we have found, on the contrary, that metaphor is pervasive in everyday life, not just in language but in thought and action (Italics mine, Lakoff \& Johnson, 1980, p. 3).

Proverbs - as an expression whose meaning cannot be worked out from the meanings of its constituent words - are like metaphors do not always mean what they literally say. Proverbs can also be identified with collocations on the grounds that they constitute groups of collocated words whose meaning is not clear from the common meanings of their constituent words. Brown et al generally define proverbs as "the short, generally known, sentences of the folk that contain wisdom, truths, morals and traditional views and which are handed down orally from generation to generation" (Brown et al, 1998, p. 525). Bakalla adds to this definition that a proverb is "often used colloquially and set forth in the guise of a metaphor and in the form of a rhyme, and is sometimes alliterative" (Bakalla, 1984, p. 248). Accordingly, proverbs are not limited to one context in the source language, rather they are used over and over, and are extended to many variable contexts because of the morals they teach, or their "folk wisdom", as anthropologists prefer to describe them.

Semiotics - that branch of science which studies signs, or systems, and the processes of sign generation and usage foregrounds codes which are a set of conventions. Codes are rule-driven systems which suggest the choice of signifiers 
and their collocation to transmit the intended meanings in the most effective way. To that extent, codes represent a broad interpretative frame work used by both addressers and their addressees to encode and decode the messages. Signs may have many levels of meaning from the denotational to the connotational that is why the addresser's strategy is to select and combine the signs in ways that limit the range of possible meanings likely to be generated when the message is interpreted. Codes fix the relationships between concepts and signs. They stabilize meaning within different languages and cultures. The reverse is also true. Codes tell us which concepts are being referred to when we hear or read which signs. By arbitrarily fixing the relationships between our conceptual systems, codes make it possible for us to speak and to hear intelligibly and establish the translatability between our concepts and our languages which enables meaning to pass from speaker to hearer and be effectively communicated within a culture. This translatability is not given by nature or fixed by the goals. It is the result of a set of social conventions. It is fixed socially, fixed in culture (Hall, 1997, pp. 21-22).

Expressing his semiotic position, Umberto Eco believes that "signification encompasses the whole of cultural life." Succinctly put, Eco regards semiotics as being "a-extensive with the whole range of cultural phenomena" (Eco, 1985, p. 251). Perhaps the most significant aspect of language is the proverbs because of their signification of symbolisms. Proverbs are classified by many linguists as metaphor; and every theory of metaphor may be used to define the concept of proverbs. Examine a definition of metaphor by Eco as follows: "the substitution of one element of language for another (the operation is completely internal to the semiotic circle) but by virtue of a resemblance between their referents" (Eco, 1985, p. 251). Eco's definition is concerned with the characteristic change of the plane of perception and, linguistically, the meaning of proverbs. Consequent upon such a change is the occurrence of two referents that are comparable. Halliday (1994) contextualizes the concept of metaphor in a similar way thus: "Among the "figures of speech' recognized in rhetorical theory are a number of related figures having to do with verbal transference of various kinds. The general term for these is 'METAPHOR"' (Halliday, 1994, p. 340). Halliday postulates that proverbs are contextualized in rhetorical theory and classified as metaphor. Proverbs, as metaphoric expressions or as cultural discourse, are codified on semantic structures. Also, the aesthetic nature of a given metaphor is also produced by contextual elements or variable of language use. Thereby, Proverbs are figural and signifying acts of meaning that mediate interpretation and negotiate pragmatic signification at linguistic, philosophical and cultural levels.

Grammatically, proverbs cannot be understood from the individual meanings of its elements and can yield different sentiments when treats as separate words. Some people may prefer to be explicit and express their thoughts directly, preferring to use words and sentences in their literal sense. On the other hand, others prefer to be somewhat implicit and indirect using sayings or proverbs leave a greater impact on the audience or may be to capture their attention via presenting a funny or a metaphorical expression. According to Mieder (2004, xii), proverbs exist under the umbrella of a branch of linguistics called phraseology. This field is concerned with studying and classifying fixed phrases such as proverbs, idioms and sayings. Proverbs portray the experience and traditions of different nations; they are very similar to literary works in being a mirror that reflects the image of the traditions and cultural values of different societies (Hasan-Rokem, 1990).

Therefore, proverbs - due to different linguistic approaches - are of several types: 1) The straightforward proverbs which do not require any transference of meanings or rhetorical styles; 2) Proverbs with metaphorical quality where there is transference of meaning from literal to figurative. A proverb - in this sense - is an embellished way of expressing wisdom, advice, etc. This last type - which extends far beyond the literal meaning - is the most preferred and practiced by people.

\section{Proverbs: Signifiers of Verbal/Social Communication}

Proverbs can be regarded as tools of verbal communication since the use of proverbs by a language user/addresser is an attempt at supporting an individual point of view, in response to a particular situation, by referring to a collective view, representative of a particular culture (Kussi, 1998, p. 2998). Thereby, language is a social mechanism, and it is learned and used within a socio-cultural context. Moreover, it is the main channel for social interaction between people of different cultures, and it is steeped in the socio-cultural context in which those peoples interact. Communication among people of different cultural backgrounds is thus complex and can sometimes be confusing. Intercultural communication requires not only knowledge of the linguistic system itself, but also the development of intercultural competence, where learners become familiar with and understand the foreign cultural behavior and subtle patterns common to the target language that shape the form and content of the interaction (Witte \& Harden, 2011). Intercultural competence is the ability to interact with people from another culture in a foreign language. Intercultural competence is one of the central aims of foreign language teaching and learning. It incorporates a curiosity and an openness to the foreign culture, a knowledge of the culture's social groups and their practices, an ability to interpret events and processes in both the foreign culture and one's own culture (Byram, 2008).

While proverbs make up and reflect the cultural identity of a specific society, and despite the uniqueness of languages and the profound differences between cultures, there are proverbs that shed light on universal truths of human life, common traditions and beliefs, and such shared values as ambition, virtue, generosity, patience, friendship, loyalty, and family ties (Bakalla, 1984; Schuster, 1998). Such proverbs have bridged linguistic and cultural barriers throughout human history. For example, the idea that the words a person chooses to articulate his or her thoughts can be crucial to his or her well-being. This idea is shared by different cultures and is expressed through proverbs using different culturally based metaphors. Consider this Arabic proverb that compares the tongue to a horse: 
It might be hard for an outsider to immediately grasp the cultural significance of the proverb without knowing its original context. In the Arab culture, the horse is an extremely important animal, used in old times in warfare. If it were not treated well, it would not function properly when needed; as a result, its rider could be killed. The following set of proverbs reveal the shared value that it is better to be satisfied with what you already have rather than wish for more and risk everything. Here different cultures use the same metaphor: a bird in the hand

The English proverb says: A bird in the hand is worth two in the bush.

A Romanian proverb says: Better a bird in the hand than a thousand on the house.

An Arabic proverb says: A bird in the hand is better than ten on the tree.

An Italian proverb says: Better one bird in the cage than four in the arbor.

Proverbs are words combined together to form larger semantic units which are encoded by the speaker and decoded by the hearer by means of their underlined knowledge of the language itself. Proverbs, in this sense, have their own conceptual meaning which is "an essential part of what language is" (Leech, 1981, p. 13). The following proverbs show that the key word 'evils' is the logical or referential or denotative meaning that no two speakers would differ about:

$$
\begin{aligned}
& \text { Of two evils choose the least }
\end{aligned}
$$

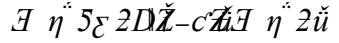

The intended meaning of a proverb cannot be effective unless the words are "associated with certain characteristics of the items to which they differ" (Palmer, 1981, p. 92). For example, people have different ideas about 'women' whether good or bad. The following borrowed proverb from French into English connotes that 'women' are the source of all evil

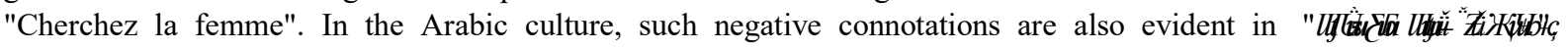
However, the positive view of 'women' is embodied in a great number of wise sayings and proverbs in Arabic literature. The following proverb is indicative: "püt make use of his previous mistakes and failures are expressed in both the English and the Arabic cultures:

$$
\begin{aligned}
& \text { A fox is not taken twice in the same snare } \\
& 5 \mathrm{~N} \\
& \text { A living dog is better than a dead lion }
\end{aligned}
$$

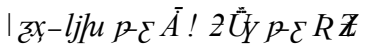

Finally, the English proverb "An eye for an eye and a tooth for a tooth" is equivalent to the Arabic proverb in both form

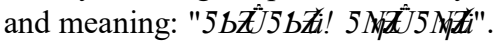

When proverbs are used in conversational situations, they "bear great weight because the speaker is linking his sayings to the past [and] by doing so, he shifts the responsibility of his content to past traditions and authorities whose wisdom cannot be questioned" (Webster, 2000). The Arabs have been fond of quoting proverbs or old sayings adopting the mode of storytelling. This foregrounds the basic nature of proverbs as conversational tools. Within this rationale, the Arabic proverbs examined in this study are mainly colloquial. The selected Arabic proverbs are taken from Ahmed

\begin{tabular}{|c|c|c|c|c|}
\hline Group & Arabic Proverbs & Literal Translation & $\begin{array}{l}\text { Assumed } \\
\text { Function } \\
\end{array}$ & $\begin{array}{c}\text { English } \\
\text { Equivalents }\end{array}$ \\
\hline $\mathbf{A}$ & من عشرة على اليد خيرة & $\begin{array}{l}\text { A bird in the hand is better } \\
\text { than ten on the tree }\end{array}$ & $\begin{array}{l}\text { Advocating } \\
\text { prudence \& } \\
\text { practicality }\end{array}$ & $\begin{array}{l}\text { A bird in hand is } \\
\text { worth two } \\
\text { in the bush }\end{array}$ \\
\hline B & 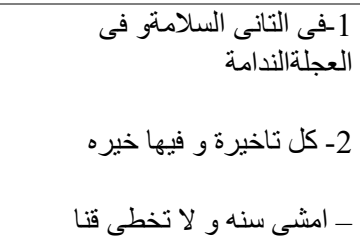 & $\begin{array}{l}\text { 1.Patience leads to safety and haste to regret } \\
\text { 2. Every delay has something good about it } \\
\text { 3. Walk for a whole year rather than cross a } \\
\text { channel }\end{array}$ & $\begin{array}{l}\text { Advocating } \\
\text { caution \& } \\
\text { patience }\end{array}$ & Haste is waste \\
\hline $\mathbf{C}$ & 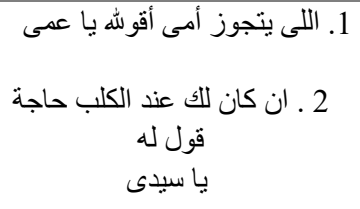 & $\begin{array}{l}\text { 1- Whoever marries my mother, I shall } \\
\text { Address him As my uncle } \\
2 \text { - If you need something From dog, } \\
\text { Address him as your master }\end{array}$ & $\begin{array}{l}\text { Advocating } \\
\text { tolerance } \\
\text { tactfulness } \\
\text { and/or } \\
\text { hypocrisy }\end{array}$ & $\begin{array}{l}\text { When you are } \\
\text { Rome, } \\
\text { Do as Romans do }\end{array}$ \\
\hline $\mathrm{D}$ & 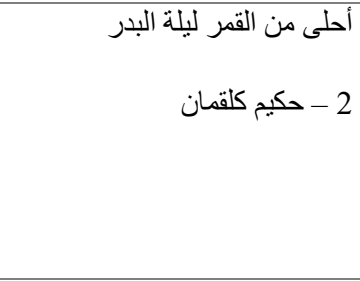 & $\begin{array}{l}1 \text { - More beautiful than the full Moon } \\
\text { As wise as Loqman }\end{array}$ & $\begin{array}{l}\text { Advocating } \\
\text { beauty } \\
\text { Advocating } \\
\text { wisdom and } \\
\text { insight }\end{array}$ & $\begin{array}{l}\text { As beautiful as a } \\
\text { lark }\end{array}$ \\
\hline
\end{tabular}
Tymour's famous book - On Egyptian Proverbs Fi average native speaker in every day conversations.

\section{Sample Proverbs}


4.1 Commentary

Upon examining groups (A, B, C and D), the following points can be noticed:

1. The Arabic proverb in group (A) tends to be much more emphatic and exaggerated when compared with its English counterpart. Instead of worth in the English proverb, there is the comparative form- $t$ th $J$ (better), and in place of two only, the Arabic proverb uses "- $N$ (ten). These two differences give an impression of excessive, caution on the part of the Arab community member. However, there is the Arabic proverb " اصر mentioned in the table. It also evokes a negative meaning and stands in contrast to the English one.

2. The English proverb 'Haste is Waste' implies a practical attitude and may be a reflection of the simple fact that when one does any job or task hastily, one may do it improperly, and, thus, may have to re-do it. Therefore, haste may literary lead to a waste of time and effort. The Arabic proverbs, on the other hand, display exaggeration and may advocate dependency or passiveness rather than warning the addressee against the adverse consequences of haste. Accordingly, there is no complain if a taxi driver, for example, loses his way in the traffic jam and causes the passenger to miss an important appointment or even a plan, just because the driver has picked up the wrong road; there should not be a problem as long as

3. The third proverb in group (B) reflects a lack of sense of time especially in agricultural societies as well as fear of the new experiences. Mohamed El-Batal -in A Dictionary of Idioms (2000) - gives the English proverb "Better safe than

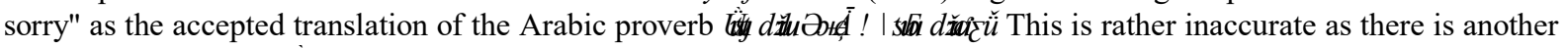

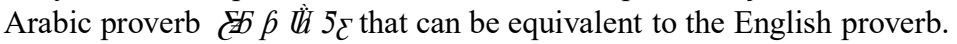

4. All the Arabic proverbs in group (A) and group (B) advocate negative or passive attitudes manifested in an exaggerated form and excessive caution. They also exhibit lack of ambition, and fear of the unknown. Even the proverb number (1) in group (B) -which seems to represent the most reasonable and moderate attitude of the three Arabic proverbs in these two groups - signifies some negative connotations associated with old myths and gothic tales that narrate the terrifying adventures of gallant heroes who have to choose between two roads: that of $F_{\mathcal{C}} \bar{a} u$ z that of $F$ اللى يروح ما يرجع $\square$ or the one-way ticket to inevitable death.

5. Upon analyzing group (C), it is obvious that it highlights other differences between the two cultures in question. The English proverb advocates tolerance and respect to others' habits and traditions whereas the two Arabic proverbs indicate mainly opportunistic and pragmatic attitude. On the other hand, the Arabic proverb dif expressive of self-dignity and self-respect. There are also $D$ d d bitter experience and the deep desire to avoid bad and hard-headed persons who abuse the poor. This pinpoints the rich diversity in the Arabic culture, that is, to find counter proverbs to convey the opposite meaning as exhibited in $Y D=4$

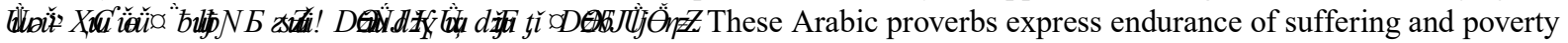
than surrendering one's self to exploitive people. Moreover, the English proverb in this group is not really the proper equivalent of the three Arabic ones, since we have an Arabic saying that reads as follows:

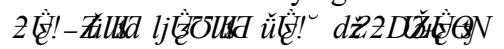

This saying is hardly Arabic in origin and it is a literal translation of the English one.

6. Group (D) are cultural idiomatic proverbs: A) The bird 'lark' - as mentioned in the English proverb - is a symbol of beauty in English culture, but not in the Arabic one. This cultural problem can be beaten by searching for the cultural equivalent simile in Arabic regardless of the difference of words. That is, 'lark' is not used in Arabic in this content, but words like $\breve{p} D \check{z}$, word in the same lexical family in Arabic, that is, to use 'nightingale' " solution is to ignore these words and take the whole simile as an expression of a specific cultural meaning which should be translated regardless of the words used in the similes. B) It is noticed from the second example that there is a gap between the two languages regarding the cultural aspect of the proverb. The English word owl stands for wisdom indicating a positive connotation while in Arabic culture it indicates a negative connotation referring to a bad omen. In this case, the translator seeks to substitute the word owl with a symbol of wisdom that has the same impact in Arabic culture $z$ LEE $C$ What . What is more, the Arabs have plenty of expressions which show that this bird brings bad luck and calamity such as لو كان فى البوم الخير ما فات الصياد. efhich emphasizes the firm belief that the owl is a signifier of pessimism and bad luck.

\section{Recapitulations}

It is worth noting that the Arabic culture is rich in its connotative meanings and is also distinguished by its diversity as manifested in the counter proverbs. In addition, the Arabic proverbs in the sample exhibit different cultural features most of which are of a negative nature in contrast with a more constructive and positive attitude that characterizes the English counterparts. In case we have to take these English proverbs as translation equivalents of the Arabic ones, we should be aware of the differences and should even make our target language reader aware of them.

It is worth remarking that no generalization is to be made on the nature of Arabic proverbs or Arabic culture as a whole. The proverbial store of any culture is bound to include many different types, some of which may contradict each other due to ups, and the many different changes each culture has to pass through. Consequently, proverbs advocating negative attitudes may originate and/or become more popular at certain times rather than others. Thereby, overgeneralization - that imposes arbitrary judgments on a whole culture - is necessarily invalid.

What is more, the translation of cultural idiomatic sayings should be carefully done. The solution is try to understand the implied meaning of the simile as displayed in the common sayings and to translate it into Arabic in some way or another giving much attention to the cultural background. 


\section{Conclusion}

Proverbs are "special, fixed, unchanged phrases which have special, fixed, unchanged meanings" (Ghazala, 1995, p. 138) and their traditional function is didactic as they contain "wisdom, truth, morals and traditional views" (Meider, 2004, p. 3). Proverbs are the transmission of people's linguistic and cultural manners from one generation into another. Proverbs are special metaphoric expressions and the translator should know the proverbial concepts in both source language SL/target language TL which means to bear in mind their similarities and differences (Nida, 1985). It is best to aim for equivalence between the proverb standing within the context of the source cultures and the target culture. This highlights Robinson's notion that the study of translation is an integral part of intercultural relations (Robinson, 1997, p. 128). The selected examples underscore the fact that a translator needs to know SL and TL cultures and its relations to their customs and traditions. Nord believes in "cultural-bound linguistic signs" and notes that "both the source and target texts are determined by the communicative situation in which they serve to convey a message" (Nord, 1991, p. 7). Thereby, the renderings of proverbs must be done with great care and not to be expected literally bearing in mind the cultural, religious and historical background of the proverbs so as to maintain the essence of meaning.

\section{References}

Al Ali, M. (2004)."Familiar Words in Unfamiliar Contexts". Perspectives: Studies in Translatology, 12(2), pp. 134-144

Bakalla, M. H. (1984). Arabic Culture Through its Language and Literature. London: Kegan Paul International.

Bassnett, S. (2002).Translation Studies. London and New York: Routledge.

Brown, M. \& B. Rosenberg. (1998). Encyclopedia of Folklore and Literature. Santa Barbara, CA: ABC-CLIO.

Byram, M (2008). From Foreign Language Education to Education for Intercultural Citizenship: Essays and reflections. Clevedon, England: Multilingual Matters.

Coles Editorial Board (1979). Dictionary of Literary Terms. Coles Notes.

Collins English Dictionary. http://dictionary.reference.com/browse/framework

Concise Oxford English Dictionary (2011).Oxford: Oxford University Press.

Dagust, M. (1976). "Can Metaphor Be Translated?" International Journal of Translation, 22 (1), pp. 12-33.

Danesi, M \& P. Perron (1999). Analyzing Cultures: An Introduction and Handbook. Bloomington, IL: Indiana University Press.

Eco, Umberto (1985). 'The Semantics of Metaphor' in (ed.) Robert E. In A Theory of Semiotics, Bloomington, Indiana University Press

El-Batal, Mohammad (2000). A Dictionary of Idioms. Cairo: Longman.

Ghazala, H. (1995). Translation As Problems and Solutions: A Coursebook for University Students and Trainee Translators. Beirut: Dar waMaktabat Al-Hilal.

Hall S. (1997). The Work of Representation: Cultural Representations And Signifying Practices. Edited by Stuart Hall.The Open University. SAGE Publications Ltd.

Halliday K. (1994). An Introduction to Functional Grammar, London: Edward Arnold.

Hasan-Rokem, G. (1990). "The Aesthetics of the Proverb: Dialogue of Discourses from Genesis to Glasnost". Proverbium, 7, 105-116.

Hofstede G. (1991). Cultures and Organizations: Software of the Mind. McGraw-Hill Book Company

Honeck, H. R. (1997). A Proverb in Mind: The Cognitive Science of Proverbial Wit and Wisdom. London: Lawrence Erlbaum Associates.

Kussi, Matt (1998). "On the Aptness of Proverbs". DeProverbio, Vol. 4, No. 1 [online].An Electronic Journal of International Proverb Studies. http://http://www.deproverbio.com

Lakoff, G. and Johnson, M. (1980).Metaphors We Live By. Chicago: University of Chicago Press. Larousse, P. 1997.

Larousse encyclopédique. Paris: Larousse Burdas.

Leech, G. \& Short, M. (1981). Style in Fiction. Longman: London.

Mandelblit, N. (1995). "The Cognitive View of Metaphor and its Implications for Translation Theory". Translation and Meaning, 18 (3), pp. 483-495.

Mieder, W. (1993).Proverbs are Never out of Season: Popular Wisdom in the Modern Age. New York: Oxford University Press.

Mieder, W. (2004).Proverbs: A Handbook. USA: Greenwood Press

Nadjib, A. M. (2001). The Basis of English/Arabic/English Translation. Egypt: Ibn Sina Bookshop PrintingDistributing-Exporting.

Nida, E. (1985). Translating Means Translating Meaning: A Sociosemiotic Approach to Translation. Leiden: E. J. Brill. Nord, C. (1991).Text Analysis in Translation: Theory, Methodology and Didactic Application. Amsterdam: Rodopi. 
Palmer, F. (1981). Semantics. Cambridge: Cambridge University Press.

Robinson, D. (1997). Becoming A Translator: An Accelerated Course. London: Oxford.

Seidl, J. \& McMordie, W. (1978).English Idioms. Oxford: Oxford University Press.

Schuster, E. (1998). "Proverbs: A Path to Understanding Different Cultures". Journal of Extension, Vol. 36(1).http://www.joe.org/joe/1998february/tt2.php.

Webster, Shelia (2000)."Arabic Proverbs and Related Forms". DeProverbio, Vol. 6, No. 2 [online].An Electronic Journal of International Proverb Studies. http://www.deproverbio.com

Witte, A. \& Harden, T. (2011). "Intercultural Studies and Foreign Language Learning". Vol. 10. Intercultural Competence: Concepts, Challenges, and Evaluations. Oxford, England: Peter Lang.

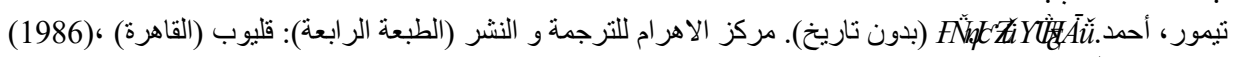

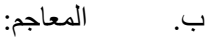

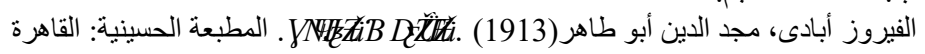

